DOI: $10.21580 /$ ihya.17.2.1735

\title{
SANKSI TINDAK PIDANA KORUPSI DALAM PERSPEKTIF FIQIH JINAYAT
}

\author{
M. Wahib Aziz \\ Sekolah Tinggi Agama Islam Negeri (STAIN) Al-Fatah Jayapura \\ E-mail:wahibstainjaya@gmail.com
}

\begin{abstract}
Islamic Shariah functioned by God as a deterrent to evil. Jurisprudence of Jinayat in Islamic law recognizes three kinds of punishment for a crime committed by a person; Qishah, hudud and ta'zir. The determination of punishment is not merely a revenge, but rather a goal to create a deterrent effect or shock to create a calm and peaceful society situation as the message contained in the word hayah which means a peaceful life. This paper aims to reveal the concept of punishment in the crime of corruption in the eyewear of Jinayat jurisprudence. Through literature review it can be concluded that the sanction of corruption is ta'zir, which is adjusted with the judge's decision based on the level of corruption that has been done. Sanctions in the form of ta'zir vary from mild to severe enough to recall corruption with a complex social impact. The ta'zir sanctions that can be given to the perpetrators of corruption are; Imprisonment, defamation, material fines to death penalty.
\end{abstract}

Keywords: Fikih Jinayat; Criminal Actions; Corruption; Sanctions; Ta'zir

\begin{abstract}
ABSTRAK
Syariat Islam difungsikan Allah sebagai pencegah kejahatan. Fikih Jinayat dalam syariat Islam mengenal tiga macam hukuman atas kejahatan yang telah dilakukan oleh seseoorang; qishah, hudud dan ta'zir. Penetapan hukuman tidak hanya sekedar pelampiasan dendam, namun lebih pada tujuan untuk menimbulkan efek jera atau shock terapy agar tercipta situasi masyarakat yang tenang dan damai sebagaimana pesan yang terkandung dalam kata hayah yang artinya kehidupan yang damai. Tulisan ini bertujuan untuk mengungkap konsep hukuman dalam
\end{abstract}


kejahatan korupsi dalam kacamata fikih Jinayat. Melalui kajian literature dapat disimpulkan bahwa sanksi tindak pidana korupsi adalah ta'zir, yaitu disesuaikan dengan keputusan hakim berdasarkan kadar korupsi yang telah dilakukan. Sanksi berupa ta'zir ini beragam dari yang ringan hingga yang cukup berat berat mengingat korupsi membawa dampak sosial yang kompleks. Sanksi ta'zir yang bisa diberikan kepada para pelaku korupsi adalah; penjara, pencelaan, denda materi hingga hukuman mati.

Kata kunci: Fikih Jinayat; Korupsi; Sanksi; Ta'zir; Tindak Pidana

\section{A. Pendahuluan}

Korupsi adalah kejahatan yang sangat berbahaya.Bahkan lebih berbahaya dari pada terorisme.Jikalau aksi teroris "hanya" menewaskan beberapa orang seperti kasus bom Bali atau di Mumbai India, tetapi korupsi bisa membunuh seluruh warga negara yang berjumlah jutaan.Hal ini karena korupsi menghancurkan dan meremukkan sendi perekonomian negara.Jika sendi perekonomian negara hancur, maka berarti kehidupan warga negara terancam.Bahkan bisa terjadi krisis besar yang bisa berakibat kelaparan, pertikaian antar warga negara, kekacauan, salingtidak percaya, disintegrasi, dan sebagainya.

Kasus korupsi milyaran di Indonesia oleh pegawai perpajakan baru-baru ini menunjukkan begitu rumit dan sistematisnya tindak pidana korupsi.Karena korupsi dilakukan secara berjama’ah, sehingga untuk mengusutnya, diperlukan upaya keras dari para penegak hukum.

Memang aparat pemerintah telah menghukum pelaku tipikor(tindak pidana korupsi) ini. Namun terdapat kesanbahwa hukuman itu terlalu ringan, hanya beberapa tahun saja.Sehingga dampak berupa efek jera tidak tercapai.Dari sinilah, maka diperlukan hukuman alternatifyang lebih tegas.

Saat ini muncul pemikiran dari akademisi dan praktisi hukum untuk mengeksekusi mati pelaku tipikor.Wacana ini mengemuka sebagai jawaban terhadap lemahnya hukum bagi koruptor.Jika kita cermati, masyarakat Indonesia secara mayoritas memeluk agama Islam.Tentu saja mereka dituntut untuk sadar menerapkan syariat Islam.Hal ini sesuai dengan perintah Allah SWT. "Jika seorang mukmin laki-laki dan perempuan ditentukan hukum oleh Allah dan Rasul-Nya dalam suatu perkara, maka tidak pantas untuk memiliki pilihan lain". 
Kesadaran ini kemudian membawa pertanyaan.Apakah hukum Islam juga mengatur masalah pidana korupsi ini?Jawabannya adalah, dalam Islam terdapat alternatif hukuman ta'zir.Jika dianalisa secara mendalam, Islam memberikan ruang terbuka yang longgar bagi kita untuk memberikan sanksi di luar hudud dan qishash.Korupsi berbeda dengan pencurian.Karena itu ranah sanksi yang tepat untuk hukuman koruptoir adalah ta'zir.

Sebagai bahan komparasi, negara Arab Saudi telah menerapakan beberapa hukum Islam di antaranya potong tangan dan qishash. Menurut data peneliti guru besar Amerika Serikat (Topo Santoso, 2003: 135), penerapan hukum potong tangan dan qishash ini berdampak signifikan terhadap pengurangan angka kejahatan. Bahkan mobil mewah di parkir di depan rumah tidak membuat pencuri berani menjamahnya. Demikian juga pada saat shalat berjama'ah, kedai dagangan ditinggalkan begitu saja dan ternyata aman-aman saja,tidak ada rasa kuatir sedikitpunakan dijarah oleh penjahat.

Dalam tulisan ini, akan ditinjau secara mendalam tentang problem tindak pidana korupsi dan sanksinya dalam fiqih jinayat (hukum pidana Islam).

\section{B. Pembahasan}

\section{Definisi korupsi}

Korupsi berasal dari bahasa latincorruptus yang disalin dalam bahasa Inggris menjadi corruption atau corrupt.Sementara Bahasa Belanda menjadi corruptie (Korruptie). Kata korupsi lebih dekat sumbernya dari bahasa Belanda tersebut (Andi Hamzah, 2009:42).

Secara harfiah korupsi berarti: Kebusukan, keburukan, kebejatan, ketidakjujuran, dapat disuap, tidak bermoral, penyimpangan dari kesucian, kata-kata atau ucapan yang menghina atau memfitnah (Nurul Irfan, 2009: 43).

Sayyid Husin Alatas, intelektual Malaysia pernah menyatakan bahwa esensi korupsi adalah pencurian melalui penipuan dalam situasi yang mengkhianati kepercayaan (Nurul Irfan: 44). 
DR Samsul Anwar, guru besar UIN Sunan Kalijaga Yogyakarta pernah mengutip definsi korupsi dari kamus Websters Third New Interitoral yaitu: Ajakan (dari seorang pejabat publik) dengan pertimbanganpertimbangan yang tidak semestinya untuk melakukan pelanggaran tugas (Samsul Anwar: 43).

Dalam bahasa Arab, korupsi diartikan "fasad" yang berarti mengambil harta secara aniaya (dzalim)(Atabik Ali, 1998: 1392). Di negara Malaysia, nampaknya memakai istilah dari Bahasa Arab, karena terdapat istilah "resuwah" yang berasal dari risywah yang berarti sogok atau suap yang juga berarti korupsi (Nurul Irfan: 44).

Dalam Ensiklopedi Hukum Islam, disebutkan bahwa pada awalnya istilah korupsi di Indonesia bersifat umum. Kemudian menjadi istilah hukum sejak dirumuskannya peraturan penguasa Militer nomor PRT/ PM/06/1957 tentang korupsi. Konsideran menyebutkan: Menimbang bahwa berhubung dengan tidak adanya kelancaran dalam usaha memberantas perbuatan yang merugikan keuangan dan perekonomian negara yang oleh khalayak ramai dinamakan korupsi, perlu segera menetapkan suatu tata kerja untuk dapat menerobos kemacetan dalam usaha memberantas korupsi (Nasrun Harun dkk: 974).

\section{Definisi tindak pidana korupsi}

Tindak pidana berarti perbuatan yang melanggar larangan yang diatur oleh aturan hukum yang diancam dengan sanksi pidana (Nurul Irfan: 31). Jadi tindak pidana korupsi berarti upaya mengambil harta secara sewenang-wenang yang dilakukan pejabat atau orang tertentu dan dianggap melanggar hukum yang diancam dengan sanksi pidana.

Dari definisi ini terlihat bahwa korupsi tidak hanya dilakukan terhadap harta publik atau uang negara.Tetapi juga harta perusahaan atau suatu lembaga swasta. Misalnya seorang karyawan swasta yang menggelembungkan biaya pembelian barang, maka ia juga dianggap koruptor. Demikian juga seorang anak yang tidak memberikan uang kembalian kepada orang tuanya, maka bisa dianggap sebagai tindak pidana korupsi. 
Hanya saja, karena jumlah dana publik begitu besar, sehingga implikasi yang ditimbulkan dari korupsi keuangan negara ini menjadi sangat besar. Bahkan seorang pejabat negara bisa melakukan korupsi sampai milyaran rupiah.

Korupsi memiliki 2 unsur utama yaitu pertama: Perbuatan yang dilakukan seseorang untuk kepentingan diri sendiri, keluarga, golongan atau suatu badan yang langsung atau tidak langsung menyebabkan kerugian bagi keuangan dan perekonomian negara. Kedua: Setiap perbuatan yang dilakukan pejabat yang menerima gaji dari keuangan negara, daerah atau suatu badan yang menerima bantuan dari keuangan negara yang dengan mempergunakan kekuasaan yang dipercayakan kepadanya oleh karena jabatannya, langsung atau tidak langsung, membawa keuntungan keuangan atau materi baginya (Setiawan Budi Utomo, 2007: 20).

\section{Hukum korupsi}

Para ulama sepakat bahwa hukum korupsi adalah haram dan dosa besar (Nasrun Harun dkk: 974). Hal itu karena korupsi mengandung banyak unsur kejahatan yaitu:

1. Kecurangan dan manipulasi karena mengandung unsur penggelapan. Si koruptor melaporkan data yang tidak sesuai dengan kenyataan. Misalnya pembelian tiket pesawat dinas dilaporkan sebanyak 10 juta, padahal realitanya hanya 5 juta. Maka dalam hal ini ia telah berbuat curang karena mengambil uang 5 juta untuk dirinya.

2. Kedzaliman karena merugikan rakyat yang telah membayar pajak. Dzalim adalah berbuat sewenang-wenang. Dosanya sangat besar. Dan membawa dampak yang berbahaya baik di dunia dan akhirat. Rakyat kecil yang tidak berkuasa didzalimi oleh penguasa, pejabat dan petugas negara karena haknya dalam bidang kesehatan, pendidikan dan fasilitas umum terhalangi karena dana pembiayaan untuk sarana tersebut dikorupsi.

3. Khianat karena melanggar dan menyalahi sumpah jabatan. Seorang pejabat atau petugas negara telah disumpah dengan kitab suci bahwa mereka akan bertanggung jawab dan melaksankan tugas yang diembankan dengan penuh amanah. Tetapi dalam perjalanannya ia 
tidak menjalankan sumpah itu dan berbuat menyimpang. Sikap ini dianggap sebagai bentuk khianat yang dilarang Allah SWT: "Wahai orang-orang beriman, janganlah kamu mengkhianati Allah, Rasul dan mengkhinati amanah-amanah yang telah diberikan kepada kamu". Dalam ushul fiqih, fil nahi menunjukkan akibat haram.

4. Tindakan kolusi dengan memanfaatkan fasilitas negara. Modusnya yaitu bekerjasama dengan pihak tertentu untuk menyelewengkan uang negara. Atau juga menerima suap dari pihak tertentu. Atau juga dalam pengangkatan pegawai negeri. Tentu saja, sikap kolusi ini sangat merugikan negara. Karena calon pegawai yang semestinya direkrut dari hasil seleksi yang adil dan taransparan tenyata diselewengkan karena menerima titipan dari kolega.

\section{Bentuk dan model korupsi (Setiawan Budi Utomo: 21)}

Korupsi memiliki beberapa varian dan model yang bisa dijelaskan berikut ini:

\section{a. Ghulul (penggelapan)}

Ghulul (penggelapan): Dalam hal ini terdapat kisahterkenal dalam perang Uhud. Yaitu ketikaterjadi kehilangan kain wol berwarna merah. Bagian pada saat itu 1/5 untuk Allah dan Rasul, dan 4/5 untuk pejuang. Padahal biasanya pembagian harta rampasan langsung diberikan untuk sahabat. Banyak gunjingan dan desas-desus kecurigaan mengenai harta yang hilang itu termasuk kepada Rasulullah. Kuatir masalah ini menimbulkan fitnah dan berkepanjangan, maka turunlah ayat surat Ali Imran : "Dan tidak pantas bagi seorang Nabi untuk menggelapkan barang. Barangsiapa menggelapkan, maka akan datang di hari kiamat dengan barang yang dgelapkannya". (Waryono Abdul Ghafur: 85)

Allah menegaskan bahwa barangsiapa yang berbuat penggelapan, maka akan membawa barang hasil penggelapannya itudi hari kiamat. Dari redaksi inilah, maka jelas bahwa hukum penggelapan adalah haram.

Dalam sejarah Islam, terdapat kisah teladan dari khalifah Umar bin Abdul Aziz yang kedatangan seorang tamu. Beliau menayakan kepada tamunya, apakah berkaitan dengan urusan pribadi atau urusan negara. Tamu itu menjawab bahwa kedatangannya terkait dengan urusan pribadi. 
Khalifah lantas memadamkan lampu.Ia mengatakan bahwa lampu itu milik negara yang tidak boleh dipakai untuk kepentingan pribadi. Tamu itu akhirnya mau mengerti.

\section{b. Risywah (Suap)}

Risywah: Suap: Berasal dari kata:Rassysa Yarussyu yang artinya memercikkan. Menurut Istilah Risywah berari memberikan sesuatu dengan adanya maksud tertentu dari pemberi kepada penerima. Mengenai risywah ini, Rasulullah bersabda: "Allah melaknat si Penyuap,penerima. (HR Ahmad). Dalam riwayat lain ada tambahan yaitu, arra'isy(makelar atau broker).Mencermati redaksi hadits di atas, jelas bahwa hukum korupsi adalah haram. Karena Allah melaknat penyuap, penerima suap, dan juga makelar suap sebagai perantara di antara keduanya.

Di Indonesia ini, suap sudah menjadi budaya dan tradisi.Suap berdampak besar dan merugikan banyak aspek kehidupan. Di antaranya adalah menghilangkan hak orang lain. Risywah atau suap merupakan salah satu bentuk korupsi.Ini mengingat suap merupakan peyelewengan untuk memperkaya diri.Banyak kasus di Indonesia seperti suap ayang dilakukan oknum pegawai kejagung, suap anggota DPR dalam pengangkatan deputi gubernur BI dan sebagainya.Petugas yang disuap menjadi tidak maksimal dalam melayani karena lebih memprioritaskan penyuap yang lebih besar duitnya. Dengan demikian, suap akan menghancurkan wibawa hukum di mata masyarakat. Hakim yang menerima suap akan menjatuhkan vonis yang tidak semestinya, menyalahkan orang yang benar dan membenarkan yang salah.

Dalam sejarah Islam, terdapat seorang pemungut pajak bernama Ibnu Qutaybah dari suku Uzdi yang ditunjuk untuk memungut pajak dari Bani Sulaim. Ia kemudian mendapat hadiah dan menghadap Rasul. Ia mengatakan:"Wahai Rasul, ini untuk anda, dan ini untuk saya”.Mendengar pengakuan Ibnu Qutaybah ini, beliau marah. Ada urusan apa, seorang petugas menyatakan ini untukku dan ini untuk Rasul. Apakah dia ketika duduk di rumah bapak dan ibunya kemudian mendapatkan hadiah itu. Kemudian beliau mengumumkan hal itu di depan khalayak (Setiawan Budi Utomo: 21). 
Pernah suatu waktu petugas Baitul Mal khalifah Umar bin Abdul Aziz memberikan kalung kepada puteri khalifah. Melihat hal itu, khalifah menyuruh puterinya agar segera mengembalikan hadiah tersebut. Khalifah tidak ingin pemberian itu berbau penyuapan atau mengandung percampuran harta pribadi dengan harta negara (Setiawan Budi Utomo: 21).

Menarik untuk dicermati, bahwa terdapat risywah (suap secara halus) terhadap pejabat.Modus ini biasanya dengan mengundang pejabat untuk memberikan pengarahan ke lembaga, misalnya lembaga pendidikan. Kemudian pimpinan lembaga memberikan transport dan uang saku kepada pejabat tadi. Tujuannya agar dalam jangka waktu tertentu petugas atau pegawai tersebut membantu kelancaran pencairan dana bantuan pendidikan kepadanya. Bahkan pengawas Ujian Nasional diberi uang saku agar tidak terlalu ketat dalam mengawasi ujian.

Ada lagi yang menarik yaitu pejabat akreditasi diminta untuk membimbing proses melengkapi berkas akreditasi. Kemudian tentu saja, ia mendapat uang saku yang bertujuan untuk memuluskan proses akreditasi sehingga nilai akreditasi menjadi sangat baik. Atau juga dewan juri dari suatu perlombaan diminta untuk membimbing peserta kemudian diberi imbalan uang saku dalam jumlah besar.

Suap secara halus dengan berbagai modus ini lebih berbahaya dari suap biasa. Dampaknya bisa sangat luas. Di antaranya merugikan orang lain, dan mengakibatkan penerima suap akan bertindak sangat subyektif dan mendukung pelaku suap.

Oleh karena itu, tidak heran bila Allah bukan saja melarang suap, tapi juga melaknat (menjauhkan dari rahmat). Allah yang bersifat Rahman Rahim tidak memberikan rahmatnya kepada pelaku suap.Demikian juga Rasul bersikap sangat tegas kepada Ibnu Qutaybah dalam hal meneriman uang suap dari wajib pajak.

\section{c. Khianat terhadap amanah}

Khianat terhadap amanah :Para koruptor mengkhianati sumpah jabatan. Karenaia diangkat sebagai pejabat, harus memenuhi janjinya dalam sumpah jabatan. Dalam Al-Qur'an dinyatakan:"Wahai orang 
yang beriman, jangan mengkhianati Allah, dan Rasul dan mengkhianati amanat-amanatmu".

\section{d. Ghasab}

Ghashab berarti mengambil harta seseorang dan merampasnya dengan paksa dan semena-mena (Sayyid Sabiq, 1992: 236). Hukum ghashab adalah haram.Jika dicermati, seorang koruptor bertindak sewenang-wenang terhadap harta orang lain (rakyat).Sebab rakyat berada dalam wilayah yang lemah, tidak berkuasa. Sayyid Sabiq, pengarang fiqih Sunnah menyitir dalil ghashab dengan surat Al-Kahfi ayat 79 yang mengkisahkan seorang penguasa yang biasa merampas perahu nelayan yang masih bagus (Sayyid Sabiq, 1992: 236). Kasus perampasan itu sama dengan kasus korupsi. Aparat pemerintah berkuasa terhadap anggaran telah melakukan tindakan semena-mena menganiaya rakyat dengan cara menggelapkan uang mereka.

\section{Fiqih Jinayat}

Fiqih berarti ilmu untuk mengetahui hukum-hukum syariat yang berkaitan dengan perbuatan anggota (perilaku lahiriah muslim)(Sulaiman Rasyid: 12). Bahjat Utaybah, ulama' Mesir menyatakan bahwa fiqih secara bahasa berarti paham secara mendalam atau mengerti terhadap sesuatu. Sedangkan secara istilah atau syara' berarti: mengetahui hukum-hukum syariat yang bersifat amaliyah (praktis) yang didapatkan dari dalilnya yang terperinci (Mohammad Bahjat Utaybah: 4).

Fiqih dapat dibagi menjadi fiqih ibadah seperti shalat, zakat, puasa dan haji. Ahwal syakhsyiyyah yaitu berkaitan dengan kehidupan keluarga seperti pernikahan, talaq, wakaf, dan waris. Kemudian juga yang berkaitan dengan tata negara yang dinamakan fiqih siyasah.Dan yang berkaitan dengan jual beli yang dinamakan fiqih muamalat.Kemudian berkaitan dengan tindak pidana yang dinamakan dengan fiqih jinayat yang termasuk juga masalah peradilan ( $q a d h a^{\prime}$ ) (Qadri Azizy, 2002: 39). Menurut Prof. Dr.H.Ahmad Rofiq, guru besar UIN Walisongo Semarang, bahwa dalam Al-Qur'an istilah fiqih disebutkan sebanyak 20 kali (Ahmad Rofiq, 2003: 4). 
Prof Jazuli dari UIN Bandung menyatakan bahwa Fiqih Jinayat adalah fiqih yang mengatur cara-cara menjaga dan melindungi hak Allah, hak masyarakat, dan hak individu dari tindakan-tindakan yang tidak dibenarkan menurut hukum. Materinya adalah pembunuhan, penganiayaan, zina, qadzaf, sariqah (pencurian), hirabah (perampokan dan pegacauan), pemberontakan, mengkonsumsi minuman keras dan murtad, serta pembahasan mengenai ta'zir (Ahmad Jazuli, 2005).

\section{Aplikasi fiqih jinayat di era modern}

Saat ini fiqih jinayat sudah jarang sekali diterapkan di dunia muslim. Ini mengingat begitu lamanya penjajahan di berbagai belahan dunia Islam.

Indonesia yang mengalami 350 tahun dijajah Belanda,mewariskan KUHP yang bernama Wet book Van Scrahft (Topo Santoso, 2003). Pedoman KUHP inilah yang menjadi panduan para penegak hukum untuk menjatuhkan sanksi pelaku pidana.KUHP ini tersebut begitujauh dari hukum Islam.Misalnya pembunuhan yang semestinya dihukum qishash tetapi ternyata hanya dihukum penjara.Tindak pidana perzinaan hanya dibiarkan saja tanpa hukuman, padahal dalam pidana Islam dihukum rajam dan cambuk.

Hanya beberapa negara yang masih memberlakukan hukum pidana Islam ini, misalnya Arab Saudi dengan hukuman pancung bagi pembunuh dan potong tangan bagi pencuri.

Meski demikian, banyak ulama dan cendekiawan optimis bahwa hukum pidana Islam bisa dimasukkan dalam KUHP.Tentu saja dengan upaya keras untuk menjadikan fiqih jinayat Ini mudah dipahami dan diterapkan secara teknis dalam lingkup hukum Indonesia.Dalam hal ini banyak pihak harus dilibatkan, baik akademisi maupun praktisi hukum.

\section{Hukuman Koruptor Menurut Fiqih Jinayat}

\section{a. Tujuan hukuman}

Hukum Islam memiliki tujuan dan maksud tertentu.Menurut penulis buku Al-Muwafaqaat, imam Syathibi (Imam Syathibi: 12), bahwa tujuan ditetapkannya hukum syariat disebut dengan maqaashidusyariah 
yang menetapkan bahwa syariat bertujuan untuk kemaslahatan manusia. Secara global, dapat dirangkum menjadi 5 hal, yaitu: Hifdzuddin (menjaga agama), hifdzunnafs(menjaga jiwa/nyawa), hifdzul aql (menjaga akal), hifdzunnasl (menjaga keturunan), dan hifdzul maal (menjaga harta).

Dalam upaya menjaga 5 komponen itulah, maka harus dilakukan beberapa upaya, diantaranya menindak pelaku kejahatan.Tujuannya bukan untuk bersikap kejam, tetapi justru mewujudkanketenangan dan ketenteraman di tengah masyarakat.Seperti hukuman qishash bertujuan untuk mewujudkan "hayat" yaitu ketenteraman di tengah masyarakat agar masyarakat tidak merasa diteror dengan pembunuhan. Hal itu telah ditegaskan Allah dalam kitab suci Al-Qur'ansurat Al-Baqarah ayat 179.

Inilah sebenarnya hikmah hukuman yang dibahas dalam Fiqih Jinayat.Semata-mata adalah demi keadilan, dan bukan kekejaman.Banyak pihak menuduh aspek sanksi pidana Islam sebagai ekspresi kekejaman dan pelanggaran HAM.Tetapi jika direnungkan dan diamati secara mendalam, dampak dari hukuman itu justru sangat positif.

Misalnya hukuman potong tangan bagi pencuri di negara Arab Saudi.Ketika hukuman itu diterapkan, maka mobil yang diparkir di depan rumah aman meski tidak dimasukkan ke dalam garasi. Intensitas kasus pembunuhan di Arab Saudi menurun tajam (Topo Santoso) dan lebih jarang terjadi di banding dengan Negara kita di Indonesia. Sebagai bahan komparasi, bahwa hukuman pembunuhan di Indonesia hanya hukuman fisik penjara sekitar $12-20$ tahun.

\section{b. Jenis hukuman}

Dalam fiqih jinayat, kriminalitas atau kejahatan dapat dibagi menjadi 3 bagian (Sayyid Sabiq: 497) yaitu:

1. Qishash adalah tindak pidana yang menyakiti atau melukai tubuh sehingga hukumannya sepadan misalnya menghilangkan nyawa, melukai anggota badan. Di Arab Saudi, praktek qishash bagi pembunuhan adalah dengan cara dipancung. Sementara di Iraq dengan cara digantung.Menurut Sayyid Sabiq, Qishash ini adalah untuk memenuhi hak sesama manusia (Sayyid Sabiq: 497).

2. Hudud adalah ketentuan pasti hukuman yang ditetapkan syariat yaitu: Hadd zina, qadzaf, minuman keras, pencurian, baghy 
(pemberontakan), judi, riddah. Hal ini untuk memenuhi hak Allah SWT.

3. Ta'zir Yaitu hukuman di luar hudud dan qishash yang ditetapkan sesuai dengan ketetapan hakim di pengadilan.

\section{Hukuman Koruptor Adalah $\mathrm{Ta}^{\prime} z i r$}

Korupsi berbeda dengan tindak pidana pencurian.Para ulama mensyaratkan sahnya pencurian apabila barang yang diambil tersimpan dan di luar penguasaan pencuri ( $f$ hirzihi).Sementara harta yang dikorupsi berada dalam wilayah kekuasaan pelaku.Ia mendapat mandat penuhdan amanah dari rakyat untuk mengelola anggaran untuk digunakan sebesarbesarnya bagi kemakmuran masyarakat (Nurul Irfan: 44).

Dariperspektif inilah, maka pencurian berbeda dengan korupsi. Korupsi bisa disamakan dengan ghulul (penggelapan) sebagaimana yang terjadi dalam kisah raibnya harta rampasan perang saat perang Uhud. Tetapi yang sedikit berbeda yaitu bahwa harta yang diambil berada dalam wewenang pelaku.

Misalnya kasus korupsi gubernur aceh dalam pembelian helikopter (Depag, 2009). Ia diberi mandat untuk mengelola APBN rakyat Aceh. Tetapi justru diselewengkan untuk kepentingan pribadi.Harga pembelian helikopter digelembungkan (mark-up) dan sisanya masuk kantong pribadi sehingga negara dirugikan milyaran rupiah.

Jika didalami, tindak pidana korupsi ini lebih condong kepada pengkhianatan amanah.Sehingga jika demikian maka hukumannya berada di luar wilayah hudud dan diserahkan sepenuhnya kepada kebijakan pemerintah.

Dalam kasus penerimaan suap yangh dilakukan oleh Ibnu Qutaybah,Rasulullah tidak menghukum dengan hukuman pencurian. Tapi beliau mengumumukan di depan khalayak agar perbuatan itu tidak ditiru. Dalam fiqih jinayat, tindakan beliau ini dinamakan tasyhir(mengumumkan untuk membuat pelaku jera).

Dalam kondisi ini, pemerintah mempercayakan peradilan kepada hakim. Untuk kasus di Indonesia, ranah ini masuk dalam wilayah peradilan umum. Hal ini karena peradilan agama tidak berwenang menanganinya. 
PA hanya berwenang menangani kasus perkawinan, cerai, wakaf dan waris.Kecuali nanti pemerintah memberikan wewenang tambahan, maka masalah pidana bisa ditangani oleh peradilan agama.

Dalam merespon sanksi korupsi ini, terdapat kaidah yang sangat terkenal, yaitu tasharruful imam alarra'iyati manuuthun alal mashlahah. Artinya kebijakan pemerintah terhadap rakyat bergantung kepada kemaslahatan.Dalam kasus korupsi di Indonesia, tentunya harus dibedakan jumlah harta yang dikorupsinya.Semakin besar harta yang dikorupsi, maka hukuman semakin berat, bahkan bisa mengarah kepada hukuman mati.

Kemudian hakim juga harus melihatkondisi dan aspek sosiologis. Yaitu bahwa Indonesia merupakan negara yang sangat korup. Sehingga hukumannya harus lebih berat dari pada hukuman korupsi di negara lain. Dalam hal ini negara kita sudah memiliki pengadilan tipikor di Jakarta. Oleh karena itulah, hukuman koruptor ini berbeda dari satu negara ke negara lain. Kita bisa mengaca sanksi koruptor di Cina yaitu hukuman mati.Dengan adanya hal itu, maka para pejabat menjadi sangat takut untuk melakukan korupsi. Kebijakan pemerintah Cina patut menjadi pertimbangan bagi hakim untuk memberantas tipikor di negara yang memiliki budaya korupsi ini.

Dengan demikian,sanksi ta'zir dalam fiqih jinayat ini sudah diterapkan oleh hakim di Indonesia.Hanya saja, keputusan yang dijatuhkan masih terasa ringan bila dibanding perbuatannya.Karena itu masih harus terus dievaluasi secara cermat dan teliti.

DR Setiawan Budi Utomo menjelaskan variasi hukuman ta'zir ini dengan mengutip buku Tasyri' Jinaiykarya intelektual Mesir Abdul Qadir Audah, bahwa dalam sejarahnya, hukuman ta'zir terdiri dari beberapa macam yaitu: Pertama: Hukuman peringatan, ancaman,dan teguran. Dalam riwayat Bukhari Muslim, Nabi Muhammad Saw pernah menghukum Abu Dzar dengan dampratan sebagai takzir karena menghina ibu dari sahabat Bilal bin Rabah. Bahkan Ia disuruh mencium kaki Bilal. Kedua: Hukuman penjara, baik bersifat sementara (penahanan) seperti Nabi SAW yang pernah menahan seseorang yang menjadi tersangka pencurian unta (HR Abu Dawud, Ahmad, Nasa'i) maupun penjara yang bersifat tetap terhadap seseorang yang berulang kali melakukan tindak pidana ta'zir. 
Dalam bahasa Arab ada dua istilah untuk hukuman penjara, pertama yaitualhabsu yang kedua assijnu. Pengertian alhabsumenurut bahasa adalah alman'u yang artinya mencegah atau menahan. Kata alhabsu diartikan juga assijnu. Karena itulah, kedua kata tersebut mempunyai arti yang sama (Wardi Muslih: 261).

Wardi menambahkan bahwa menurut imam Ibnul Qayyim dalam kitab aththuruq alhukmiyyah, bahwa yang dimaksud dengan Alhabsu menurut syara' bukanlah menahan pelaku di tempat yang sempit, tetapi menahan seseorang dan mencegahnya agar ia tidak melakukanperbuatan hukum, baik penahanan tersebut di dalam rumah atau masjid maupun di tempat lainnya. Penahanan model itulah yang dilaksanakanpada masa Nabi danAbu Bakar.

Menurut Wardi,dosen IAIN Serang Banten ini, bahwa dapat disimpulkan, pada masa Nabi dan Abu Bakar tidak ada tempat yang khusus yang disediakan untuk menahan seorang pelaku kejahatan. Tetapi setelah jumlah umat Islam bertambah banyak dan wilayah Islam bertambah luas, Khalifah Umar pada masa pemerintahannya membeli rumah Shafwan bin Umayyah dengan harga 4000 dirham untuk selanjutnya dijadikan sebagai penjara. Atas dasar kebijakan khalifah Umar inilah para ulama membolehkan kepada ulil amri(pemerintah) untuk membuat penjara. Meskipun demikian, para ulama yang laintetap tidakmembolehkanuntuk membuat penjara, karena hal itu tidak pernah dilakukan oleh Nabi maupun Abu Bakar (Wardi Muslih: 261).

Wardi menganalisa bahwa dalam Al-Qur'anul Karim pada surat annisa' ayat 15 disebutkan bahwa pada awalnya,hukuman wanita yang melakukan zina adalah dikurung seumur hidup sampai datang ajalnya. Sanksi ini diambil sebelum turunnya ayat surat Annur yang menjelaskan hukuman pezina ghairu muhsan dan hadits Nabi yang menjelaskan sanksi bagi pezina muhsan. Allah berfirman: "Dan (terhadap)para wanita yang mengerjakan perbuatan keji, hendaklah ada empat orang saksi di antara kamu (yang menyaksikannya). Kemudian apabilamereka telah memberi persaksian, maka kurunglah mereka(wanita-wanita itu)dalam rumah sampai mereka menemui ajalnya, atau sampai Allah member jalan yang lain kepadanya".

Alasan lain dibolehkanya hukuman penjara sebagai ta'zir adalah tindakan Nabi SAW yang pernah memenjarakan beberapa orang di 
Madinahdalam tuntutan pembunuhan. Juga kebijakan khalifah Utsman yang pernah memenjarakan Dhabi' ibnul Harits salah satu pencuri dari Bani Tamim, sampai ia mati di penjara. Demikian pula khalifah Ali pernah memenjarakan Abdullah bin Zubair di Makkah, ketika ia menolak untuk membaiat Ali (Wardi Muslih: 262).

Ketiga:Hukuman penyaliban sebagaimana yang dilakukan Rasulullah terhadap pelaku tindak keonaran dan pembangkangan (hirabah), yaitu Abu Nab (HR Abu Dawud dan Ahmad)

Keempat: hukuman mati bagi provokator, mata-mata, penyebar fitnah, dan pembuat makar. Kelima: Hukuman pengasingan atau pembuangan seperti dilakukan Umar bin Khaththab terhadap Nasr bin Hajjaj.Keenam: Hukuman publikasi Daftar Orang-orang Tercela (DOT) seperti terhadap pelaku kejahatan kesaksian palsu, dsb. Ketujuh: Hukuman pencopotan jabatan seperti dikemukakan Imam Ibnu Taimiuah dan Ibnu Qayyim. Kedelapan: Hukuman penyitaan harta dan sanksi berupa denda finansial (Setiawan Budi Utomo: 22).

Hukuman ta'zir dari hakim ini bisa juga menggunakan hukum mati.Seperti kita cermati dalam konteks modern ini, yaitu kebijakan Perdana Menteri Cina tahun 1998, Zhu Rong jie (Depkominfo: 39). Saat ia menjabat, korupsi begitu mewabah di negeri itu. Ia bertekad untuk memberantasnya sampai akar-akarnya. Ia berucap:"Sediakan saya 100 peti mati: 99 peti untukkoruptor dan 1 untukku apabila melakukan hal yang sama".

Dalam tiga tahun pemerintahannya sampai tahun 2001, kurang dari 4000 orang ditembak mati di depan umum karena korupsi. Pada kuartal pertama 2003 teradapat 33.761 polisi dicopot karena terkena isu suap, mabuk, judi, membawa senjata api di luar tugas, dan kualitas SDM nya di bawah standar.dan pelanggaran lainnya. Sejak korupsi diberantas, Cina berhasil mendongkrak laju ekonominya sampai 10,7 persen pertahun. Itu merupakan angka pertumbuhan ekonomi yang spektakuler dan belum pernah dicapai negara manapun di dunia (Depkominfo: 39).

Menurut Wardi Muslich (Wardi: 262), untuk jarimah (kejahatan) ta'zir, hukuman mati ini diterapkan oleh para fuqaha secara beragam. Hanafiyah membolehkan kepada ulul amri (penguasa) untuk menghukum 
mati apabila jarimah dilakukan secara berulang-ulang. Seperti pencurian yang berulang-ulang dan menghina Nabi berkali-kali yang dilakukan oleh kafir dzimmi, meskipun setelah itu ia masuk Islam.

Madzhab Maliki juga membolehkan hukuman mati sebagai ta'zir untuk jarimah-jarimah ta'zir tertentu, seperti spionase (mata-mata) dan melakukan kerusakan di muka bumi.

Sebagian fuqaha Syafiiyyah membolehkan hukuman mati sebagai ta'zir dalam kasus-kasus penyebaran aliran-aliran sesat yang menyimpang dari ajaran Al-Qur'an dan sunnah.Demikian pula hukuman mati bisa diterapkan kepada pelaku homoseksual (liwath) dengan tidak membedakan antara muhsan dan ghairu muhsan (Wardi: 259).

Wardi menyimpulkan dari pendapat fuqaha di atas, bahwa hukuman mati untuk kejahatan ta'zir hanya dilaksanakan dalam jarimahjarimah( kejahatan) yang sangat berat dan berbahaya dengan 2 syarat yaitu bila pelaku adalah residivis yang tidak mempan oleh hukuman-hukuman hudud selain hukuman mati. Dan selanjutnya, harus dipertimbangkan betul-betul dampak kemaslahatan terhadap masyarakat dan pencegahan terhadap kerusakan yang menyebar di muka bumi (Wardi: 260).

Menurut pandangan penulis, hukuman ta'zir bisa disesuaikan dengan tingkat kedudukan terpidana.Statemen ini merujuk kepada hadits Rasulullah SAW bersabda: "Ampunkanlah gelinciran orang-orang yang baikbaik, kecuali had-had". (HR Ahmad, Abu Dawud, Nasa'i dan Baihaqi).

Maksud dari hadits di atas, bahwa orang yang ternama atau yang terkenal shaleh dan baik, jika mereka tergelincir dalam kejahatan, maka berikanlah keringanan dalam hukuman, karena biasanya mereka melakukannya dengan tidak sengaja.Pendapat ini bisa kita rujuk kepada penulis kitab Fiqih Sunnah, Sayid Sabiq (Sabiq: 498).

Hal ini berlaku di luar hudud.Apabila berkaitan dengan hudud, maka tidak ada ampunan. Sebagaimana kisah yang sangat terkenal, yaitu seorang wanita dari Bani Makhzumiyyah, yaitu Fathimah dimintakan ampunan oleh Usamah Bin Zaid, anak angkat Rasulullah. Beliau marah dan merespon dengan bersabda: "Bangsa yang sebelum kalian hancur akibat mengeksekusi pencuri dari kalangan lemah, sementara meninggalkan eksekusi pencurian untuk kaum bangsawan". (HR Muslim). 
Pakar hukum Islam Mesir, Mohammad Bahjat Utaybah (Utaybah: 391) menyatakan bahwa ada beberapa macam ta'zir yang bisa diberlakukan dalam pidana Islam, yaitu:

Pertama: Eksekusi mati: Ia beberapa pendapat madzhab fiqih. Menurut Abu Hanifah, boleh menjatuhkan ta'zir berupa hukuman mati untuk pelaku homoseksual yang sudah terbiasa melakukannya dan pelaku aliran sesat yang berbeda dengan keyakinan dan kesepakatan umat Islam serta pencuri yang sudah berkali-kali mencuri. Sedangkan madzhab Maliki membolehkan hukuman mati sebagai ta'zir bagi mata-mata yang beragama Islam yang mengintai kaum muslimin demi kepentingan musuh serta aliran sesat.Madzhab Syafii berpendapat boleh mengeksekusi mati sebagai ta'zir bagi aliran sesat serta pelaku homoseksual. Madzhab Hambali membolehkan hukuman mati bagi pelaku mata-mata muslim yang bekerja demi kepentingan musuh. Argumentasi kebolehan eksekusi mati ini berlandaskan teks hadits yang menyuruh untuk membunuh pelaku homo seksual, penganut aliran menyimpang serta pelaku seksual kepada binatang. Hukuman mati ini banyak diterapkan di negara modern sekarang ini setelah sebelumnya diabaikan, seperti Italia, Rumania, Portugal (Bahjat: 402). Kedua: Hukuman cambukan yang kadarnya berbeda di antara pendapat para fuqaha. Ketiga: Penjara atau penahanan. Keempat: Denda finansial.

\section{Pelaksana Eksekusi Ta'zir}

Yang berwenang untuk melakukan ta'zir ini adalah hakim, karena ia telah diberikan wewenang(alwilaayah al'ammah). Ta'zir yang dilakukan selain hakim hanya dibolehkan untuk 3 personal, yaitu: ayah kepada anaknya untuk mendidik, sayyid (majikan) kepada budaknya pada jaman dulu serta suami kepada isterinya tatkala nusyuz (durhaka) (Sabiq: 500).

\section{Perbedaan Antara Korupsi dan Pencurian}

Muncul statemen beberapa kalangan yang menyamakan antara korupsi dengan pencurian (Nurul Irfan: 44). Mereka beranggapan bahwa pencuri dan koruptor sama-sama mengambil harta secara sembunyisembunyi.Sehingga koruptor juga dihukum potong tangan sebagaimana dijelaskan dalam Al-Qur'an yang masuk ranah hudud.Pendapat ini 
berlandaskan pada kesamaan definisi yaitu dalam hal mengambil secara diam-diam atau sembunyi-sembunyi.

Akan tetapi, bila dicermati dalam hal syarat tindak pidana pencurian, yaitu mengambil barang yang tersimpan.Dari persyaratan ini, maka nampak bahwa korupsi berbeda dengan pencurian.Sebab harta korupsi berada dalam kekuasaan si koruptor bukan kekuasaan pemilik harta sebagaimana dalam pencurian.

Meskipun harta yang diambil berasal dari harta rakyat, tetapi rakyat telah memberikan amanah mereka kepada pejabat atau petugas negara untuk mengelola harta tersebut.

Jika dicermati dari perspektif ini, tindak pidana korupsi lebih condong ke arah perbuatan khianat jabatan, bukan pencurian.Tetapi karena dampak yang ditimbulkan jauh lebih besar dari pencurian, maka sanksinya dapat melebihi potong tangan seperti hukuman mati.

Karena ada perbedaan dalam hal penguasaan harta korupsi ini, maka pidana korupsi tidak dapat diqiyaskan(disamakan) dengan pencurian. Sebab jika disamakan, maka tidak diterima karena masuk kategori kaidah"alqiyaas ma'al faariq" (penyamaan padahal berbeda).

\section{Analisis}

Dari paparan di atas, jelas bahwa hukuman korupsi adalah ta'zir. Sebab korupsi berbeda dengan pencurian yang dihukum dengan had potong tangan. Hukuman ta'zir itu bisa lebih berat sesuai pertimbangan hakim. Bahkan bisa mengarah kepada hukuman mati.Selama ini di negara kita belum pernah terjadi eksekusi mati bagi terpidana korupsi yang berjumlah besar. Sehingga efek jera dari perbuatan korupsi belum muncul. Hukuman mati baru diterapkan untuk pelaku terorisme, penyelundup narkotika dalam jumlah besar atau pembunuhan lebih dari satu korban. Oleh karena itu, maka alternatif hukuman ta'zir berupa sangsi seberatberatnya ini patut menjadi bahan pertimbangan kita semua.

Namun patut menjadi catatan, bahwa dalam hal ini kita harus adil. Sebagaimana ungkapan Toso santoso, dosen fakultas hukum Universitas Indonesia (Topo santoso: 137), bahwa penerapan sanksi korupsi bagi pejabat yang korupsi harus dengan memfasilitasi mereka dengan gaji yang 
cukup dan memadai.Menurut penulis, dalam hal ini, pemerintah sudah cukup tanggap.Diantaranya dengan memberikan remunerasi yang dimulai dengan 3 institusi negara yaitu Kementerian Keuangan, Badan Pengawas Keuangan (BPK) dan Mahkamah Agung.Ke depan, akan diberlakukan bagi instansi negara yang lain.

Selain itu harus ada upaya kultural melaluipembinaan mental para pegawai. Prof Imam Suprayogo, mantan rektor UIN Malang menganjurkan shalat berjama'ah agar diefektifkan sebagai terapi pencegahan korupsi (Suprayogo, 2010). Karena orang yang aktif dan tekun beragama biasanya terhindar dari kejahatan dan tindak pidana.,

Apabila kita analisa dalam perspektif korupsi sebagai ghashab(merampas dengan paksa), maka hukumannya juga ta'zir.Karena merampas harta seseorang dengan sewenang-wenang tidak diatur dalam sanksi hudud. Adapun jika dihubungkan dengan tindakan hirabah berupaperampokan dengan ciri aksi anarkis yang disanksi had, maka tidak bisa disamakan. Hal ini mengingat korupsi bukan bersifat anarkis.Dengan demikianhukumannya tidak berupa had hirabah (perampokan anarkis). Maka bisa ditarik kesimpulan bahwa, hukuman korupsi adalah adalah ta'zir sesuai ketentuan hakim.

\section{Simpulan}

1. Tindak pidana korupsi bisa berupa ghulul (penggelapan). Dalam hal ini bisa berbentuk penggelembungan anggaran, menggunakan fasilitas negara, dsb. Selain itu korupsi bisa berupa penyuapan atau sogok.

2. Fiqih Jinayat adalah hukum pidana dalam Islam. Ada 3 aspek besar di dalamnya yaitu hudud, qishash dan ta'zir.

3. Sanksi tindak pidana korupsi adalah ta'zir, yaitu disesuaikan dengan keputusan hakim. Sanksi berupa ta'zir ini bisa lebih berat mengingat korupsi membawa dampak sosial yang sangat kompleks dan parah. Ta'zir juga bisa beraneka ragam, seperti penjara,pencelaan, denda materi, bahkan bisa hukuman mati.

4. Korupsi berbeda dengan pencurian, karena barang yang diambil berada dalam wilayah kekuasaannya. Sedangkan benda dalam 
pencurian terjaga dan terlindungi serta berada dalam kekuasaan orang lain.

Fiqih Jinayat (hukum pidana Islam)sangat relevan untuk diterapkan dalam pembangunan hukum di Indonesia. Namun semuanya itu perlu bertahap dan pelan-pelan. Sama dengan hukum ahwal syakshsiyyah yang diundangkan melalui peradilan Agama. Penerapan fiqih Jinayat ini memerlukan pikiran dari para akademisi dan praktisi untuk merumuskan lebih jelas dan memasukkannya dalam RUU pidana. Bahkan menurut guru besar UI, Prof. Dr Jimly Ashsiddiqie, masih diperlukan ribuan doktor untuk mengkaji dan mengaktualisasikan kembali fikih jinayat dalam pembangunan hukum Indonesia (Suprayogo, 2010). 


\section{BIBLIOGRAFI}

Abdul Ghafur, Waryono, Tafsir Sosial, Diva Press Yogya, cet 1, 2001

Ali, Atabik, Kamus Kontemporer, penerbit Krapyak, cet 81998

Asy'ari,Musa dkk,editor,Menuju Masyarakat Anti Korupsi, Serial Khutbah Jum'at, ,Departemen Komunikasi dan Informatika, cet 1, 2005

Azizy, Qadri, Eklektisme Hukum Islam, Gama Media, Yogya, cet 1, 2002, 39

Budi Utomo, Setiawan, Fiqih Aktual, GIP, Jakarta cet 1, 2006

Haroen, Nasrun, dkk, Ensiklopedi Hukum Islam PT Ichtiar Van Hoeve, jilid 3 , cet 1 , Jkt 2001

Irfan, Nurul, Tindak Pidana Korupsi dalam fiqih Jinayat(Disertasi program doktoral UIN Syarif Hidayatullah) Jakarta, Balitbang Depag, cet 1 2008

Jazuli, Ilmu Fiqih, Prenada Media, cet 5, 2005

Muslich, Wardi, Fiqih Jinayat, Sinar Grafika, cet 1, 2004 Jakarta

Rasyid, Sulaiman, Fiqih Islam,PT Sinar Baru Algesindo, cet 39 tahun 2006.

Rofiq, Ahmad, Hukum Islam di Indonesia, Raja Grafindo, cet 6, 2003,4

Sabiq, Sayyid, Fiqhussunnah, Darul Fikr, Beirut, cet 1, 1992.

Santoso, Topo, Membumikan pidana Islam, GIP Jakarta, cet 1, 2003

Syathibi, Imam, Al-Muwafaqat, Darul Kutub Al-Ilmiyyah, Beirut jilid 2, 1998.

Utaibah, Bahjat, Alfiqh Aljinaaiy Al-Islamy, ,Departemen kajian Islam, Mesir cet 1, 2000.

Website: http/www.imamsuprayogo.com/membudayakan shalat berjama'ah, akses 2-2 2010 
